$P R+137$

\title{
ENERGY STORAGE FOR TOKAMAK REACTOR CYCLES
}

C. H. BUCHANAN

\section{PLASMA PHYSICS LABORATORY}

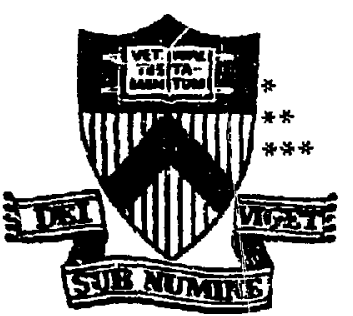

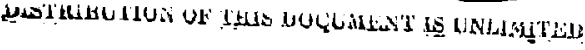

\section{PRINCETON UNIVERSITY PRINCETON, NEW JERSEY}

This work was supported by the U. S. Department of Energy Contract No. EY-76-C-02-3073. Reproduction, translation, publication, use and disposal, in whole or in part, by or for the Unfted States Government is fermittej. 
I Inergy Transifer Hechan ism

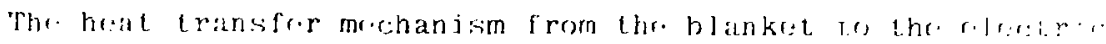

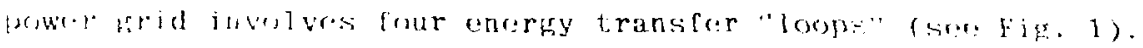
Thre plasmit roastion vesisel is surrounded by a molten salt (li ibi:j blinkel. Distribuled throughout the flibe is a fliter/hrilum he:al

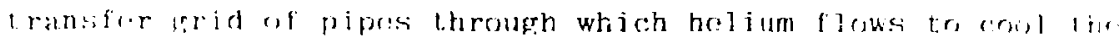
llibe. llhe hot holium, in turn, is circulated through her ium/

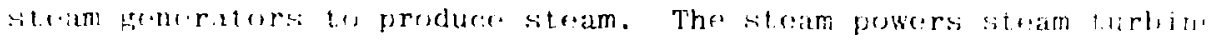

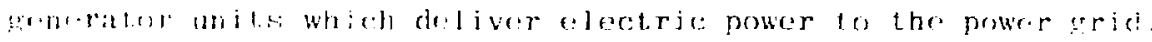
Inhreront. in the heat. transfer mechanjom is some significant

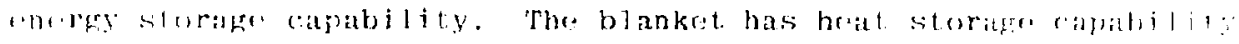
(atisumingr a 106$)^{6} \mathrm{~F}$ temperature drop) corresponding to approximate. : $35 \%$ of the total thermal storage requirement of $920 \mathrm{GJ}\left(872 \% 10^{6}\right.$ i3tu). There is some nuilear afterheat which amounts to approximalcily $5 \%$ of thr total requirement. There is additionalty some stemile in the her ium and steam volumes whose contribmtions ar. atistumid to be negligihle.

A. Flibr. I. ip

The four encrgy transfer loops of the hybrid reactor prestent $\because$ Waily of possibilities for energy storage. The flibe lon? ifires the possibilities of storage in an extra volume of flibe $\because r$ in a volume of a less expensive salt via an additional heat aschanger.

\section{B. Helium Loop}

The helium lorp offers the potential for incorporation of a variety of heat storage devices such as ceramic refractory blocks, fluidized beds, or steel tubes, referred to generally in this report as "hot rocks". 
C. Helium/Strim Intorfare

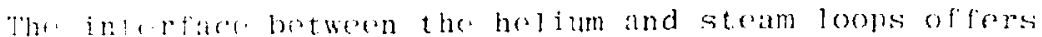
the possibilitics of intoreatod hout transfer and energy storage utilizing either the fluidized bed or the flash steam approach.

D. Ste.am Loop

The steim lomp offers the possibility of storage of steam ilisiol!.

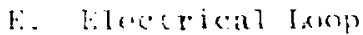

The frectrial loop of [ers the potential for utilization

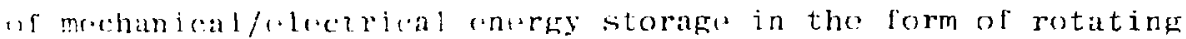
rachines incorporating flywhods, hydraulic storage in the form of pumped storage, magnetic field storage in the form of superconducting coils or siectric field storage in the form of capacitors. A furthor possibility is modification of powar grid uperating proceduros (and possibly configuration) to permit inhrrent compatibility with the reactor cycles.

II Constraints/Assumptions

The constraints and assumptions guiding this energy storage study are:

1. Electrical output to the power grid must be maintained constant at approximately $2500 \mathrm{MW}$ (except for power company operating procedure discussion).

2. Steam temperature change at the steam turbine inlet cannot exceed $50^{\circ} \mathrm{F}$. This constraint derives from data applicable to the $1000 \mathrm{MW}$ steam turbine generator units used presently in nuclear power plants. Utilization of $250 \mathrm{MW}$ units might permit a relaxation of this requirement. Designs of these smaller machines have been devezoped to permit temperature and load cycling. 
3. For metallurgical reasons, the helium temperature al the hottest belium loop point in the reactor should be limitrd to $600^{\circ} \mathrm{C}\left(1113^{\circ} \mathrm{F}\right)$. To allow a reasonable marein, a hellum hot spot temperature of $550^{\circ} \mathrm{C}\left(1022^{\circ} \mathrm{F}\right)$ is postulated.

7. Allowable helium and fll ibe temperature change during the rractor downtime is judged to be $100^{\circ} \mathrm{F}$. This judgment is based on the probability that flibe and helium mass flow rates can bo controlled to limit the steam change to the $50^{\circ} \mathrm{F}$ required by tho stram turbinfs. The heljum loop cool side tomperature must be maintained no cooler than $710^{\circ} \mathrm{F}$ to provent flibo solidification.

5. Implemritation of the enorgy storage concept will bet achieved by methols ciosely approached by stato-of-the-art to the extent that is breakthroughs are required.

\section{I Energy Storage}

Various energy storage methods incorporated into the flibe. helium, steam and electrical loops, and in the helium/steam interface were investigated. The preferred method, the rlash steam approach is one which constitutes the helium/steam interface and which ircorporates the energy starage function as well as the basic. energy transfer (steam generator) function.

One disadvantage is common to several of the approaches. It is identified in the ensuing discussion as "insufficient temperature difference" and it is based on the fourth assumption/ constraint which assumes a $100^{\circ} \mathrm{F}$ temperature excursion for the flibe and the hot side helium, and a $50^{\circ} \mathrm{F}$ excursion for the steam. When energy is transferred across a heat exchanger alternately 
in both directions (i.e., hot rncks are heated by, and then heat the heliull) and when the temperature differential is small (cannot be more than $100^{\circ} \mathrm{F}$, probably closer to $50^{\circ} \mathrm{F}$ ), the heat exchanger must necessarily have a very large heat transfer area. Size and cost are consequently large.

\section{A. Flibe Loop}

Energy storage in the flibe loop appears to be relatively ratiy albeit expensive, but the enerry retrieval appears to prosent some rather severe difliculties.

1. Fxtra F1ibe Storage

Encrey storage in an extra quantity of flibe (sep References 1 and 2 and $F j$. 2) seems, at first glance, to be attractive. Further consideration, with particular attention to the typical llow rates, raises some question as to the retrievability of the stored energy.

Retrieval must occur within the 100-second downtime. One pass of the entire inventory of molten energy storage material is assumed. The molten salt flow rates discussed in Reference 1 speak of a normal inherent blanket one-pass time of 30 minutes (page 257) and a reduced one-pass time (page 487) of 12 minutes during reactor downtime. Incorporation of the indicated extra flibe (page $487 \approx 2$ times the inberent flibe) means that it would require $3 \times 12=36$ minutes to pass all the flibe through the reactor once.

Reference 2 (page $X-E-4$ ) speaks of molten sodium flows and amounts that are equivalent to one pass of all the molten sodiun through the sodium loop in 5.5 minutes. The molten sodium loop 
in this case incorporater the energy storage function in extra molten sodium. Normalization of the 5.5 minute one-pass time to the Reference 1 equivalent power and downtime requirements yields a 14.3 minute one-pass time, assuming constant flow.

It is significant that the typical flows of References 1 and 2 , whon normalized to one passage through the loop in 100 seconds, yield values from 8.5 times (Reference 2) to 22 times (Relerence 1 ) the flows considered. It is unlikely that increasing the flow rates by these factors would be nractical from either the flow characteristic or the pumping power sitandpoints. Redesinn of the flibe system to incorporate many parallai puths, cach path consisting of a pump, inherent lifibe, and cotru energy storage flibe could achieve the necessary one-pass time. but the pumping power requirements would be essentially the same as for the 8.5 times and 22 times flow rates.

Since the hybrid reactor flibe is radioactive, a further complication is the shielding of the extra enerry storage flibc. The cost of the extra energy storage flibe alone, ruclusive of the storage containers and shielding. is estimated to be of the order of 640 million dollars. The foregoing uncertainties and cost encourage exploration of other energy storafe methods.

\section{HTS storage}

A variation of the foregoing approach incorporates (see Fig. 3) the function of the extra energy storage flibe in the form of a far less expensive irdustrial type molten salt designated as HTS. This approach, however, requires an additional heat exchanger for the flibe/HTS heat transfer. The required flibe and HTS flow rates would be well above the typical flow 
rates of References 1 and 2 . A further disadvantage of this scheme involves the insufticient temperature difference factor diseussed earlier in paragraph 4 of Section II.

B. Helium Loop

Energy storage in the helium loop can be achieved using many materials and configurations, series or parallel enerfy retrieval paths, and special high-temperature storage heating Iosps.

1. Hot Rock Bed (Series)

A hot rock bed corramics, rluidized bred. stoel lube bundle, (ote.) placed in series on the hot side of the holium loup (see Fig. 4) is penalized by the insufficient temperature difference discussed above.

2. Hot Rock Bed (Parallel)

One possible approach (see Fig. 5) to improvement of the insufficient temperaturn difference problem is to connect the hot rock bed in parallel with the hot side of the main helium flow. By appropriate valving, and by incorporation of a special high-temperature helium heat exchanger (using special materials) in the hot portion of the flibe blanket, especially hot helium can be used to heat the not rozk bed to a higher temperature than could be attained with the main flow belium. The increased temperature differential permits reduction in the size and cost of the bed, but at the expense of the special high-temperature heat exchanger and the helium flow valving.

3. Steel Tubes

In either one of the foregoing hot rock bed approaches, the use of a pebble bed or a fluidized bed introduces the need 
for some kind of impurity separator to maintain gas cleanliness. A possibility that eliminates the impurity separation requirement is the use of stecel tubes bunded in an outer shell, the steel itself serving as the heat storage medium (see Reference 3 ). C. Helium/Steam Interface Energy storage as an inter-loop function, integrating the interfacing of the helium loop and the steam loop, sughests tuos somewhat similar approaches. Both approaches incorporate dual functions inte the hardware. Roth the helium/steam enoryy transfer and the energy storage are achieved by rho samo equipmunt.

1. Fluidized Bod

The fluidized bed approach (see Fig. 6) utilizes two beat exchangers immersed in the bed, one for helium/bed transfer and one for bed/steam transfer. A separate, closed-loop helium system lluirizes the bed. The mass of bed material (rraded sand) required for the heat transfer during burn is expected to bre somrewhat inadequate for the required energy storage. However the bed material constitutes a very small percentage of the tonal cluidized bud cost so the incremental cost of the energy storage feature is judged to be negligible.

The fluidized bed approach appears present $1 y$ to require both technology and physical size development to become a really viable energy storage candidate. It is very probable, however, that its development may parallel that of tokamak reactors to the extent that both will mature into the hardware stage at the same time. 
2. Fiash Steim

a. Conirept

The flash steam concept (see Fig. 7) stores energy in containers that are filled with a water/steam combination at. a temperature determined by rerulation of the boiling point by pressure. The containers are essentially fire tube bojlers with the boiler and tube axes oriented vertically. Tho hot helium passes through the tubes and transfers its hoat through llu Lube walls to the water/steam combination which occupies the spaces between the tubus and the boiler shell.

The boiler complement constitutes a series element in the hoat transfor system, all of the helium/steam energy being transferred via the flash steam medium. Further, the boiler complement integrates the two functions of helium/steam heat transfer and the requirid downtime energy storage and recovery. During the 1000-second reactor burn, the helium transfers more uncrgy to the water/steam comoination than is demanded by the steam turbine renerator units. Thereforo there is an increase in the pressure, and hence the temperature of the boiler contents. A pressure regulator lunction governs the steam delivery to the steam turbine units. During the $100-$ sucond reactor downtime, the pressure regulator demands constant steam, thereby depleting the steam in the boilers and reducing boiler pressure. The reduced pressure lowers the boiling point of the boiler water, some of which immediriely flashes into steam and lowers the boiler contents temperature. The pressure and temperature reduction continue until the next reactor burn occurs. The flashed steam drives the steam turbine generator units for constant electrical output. 


\section{b. Preliminary Design}

Twelve boilers are required, each being 105 feft bigh and 17 fect in diameter and incorporating 4000 one and one-fourth inch tubes for an active surface area of 125,000 square feft. Each boiler is rated 250 MW electric.

Water partially fills the boiler, immersing the tuil te the 54 foot level, the remaining height being occupied by stoun. Although the boilers are 105 feet high, only 95 loet of hoirht Lis tubes. The remaining 10 feet of boiler is manifolding at tops and bottom. Hence, 11 foet of the tube height is immersed in sitritm. Approximate $1 y 39$ ceot of tube at the bottom hrats liquid water while the next 15 leet constitute the region where the steam is formed. The top 41 feet act as a superheater, perhaps making a moisture separator unnecessary.

\section{c. Cost}

The basic uninstalled cost of the helium/steam energy trinsfer system is estimated by Foster-Wheeler (boilers) and Lesli. Company (pressure regulators) to be $\$ 145,000.000$. The incremental cost of the enfrgy storage function is perhaps nonexistent in view of the fuct that the compelling fuctors determining the boiler design are the steam generation factors rathrs than the energy storage factors.

D. Steam Loop

Direct storage of steam 1 tself necessarily calls for a much greater volume than does the flash steam approach since steam density at the pressure and temperature involved is less than 5 percent of that of water. The additional boilers re- 
ruired for this approach eliminate it from further considelattion.

\section{E. Rlectrical Loop}

Energy storage in the electrical loop offers possibilitjes ranging from mechanical/electrical storage in rotating ! 1 whet:? milchines to changes in power company operating procedures. Br.twoon these lwo extremes lie techniques to store encrat in oloctric [iclds. manntic fields, and olovated water.

Any approach to energy storage in the electicical loop is predicated on the ability to throttle the steam turbines tack In some loud (perhaps 20\%) which permits them to ride trough the reactor dnwntime: on the energy stored inherently in the reactor energy transfer system. Although the design of the presently available 1000 wW turbine units does not permit such throttling. there are 250 MW designs that do tolerate this kind of operation. In view of the ract that twelve boilers, and associated preasiare regulators, would match twe ve $250 \mathrm{M}$ steam turbine units one cor one, it is possible that the final plant configuration could consist of twelve 250 MW systems paralloled at the helium loop on the suree side and at the electrical loop on the luad side.

1. Flywher Machine

The flywheel machine approach (see Fif 8) to energy storage in the electrical loop utilizes vertial shaft ac macinines with added flywhel effect. Frequency conversion between the machines and the power grid permits the necessary machine sperd excursions for energy storage and recovery. Mactines similar to 
those procured for Princeton'a TFTR program are applicable. Ninety machines in parallel are required at a typical cost of six million dollars each, for a total machine cost of 540 million dollars.

The frequency conversion function between the machines and the power grid is esimated at $\$ 130 / \mathrm{kW}$ for a total converito: cost of 312 million dollars. The combined cost approaches one: billion dollars, a value which encourages investigation of other approaches.

Use of homopolar machines and half the conversion (ac to do instead of ac to de to ac) might result in lower cost, but on] if homonolar machine developnent is presumed to have been accontplished.

2. Superconducting Coils

Marnetic field energy storage (see Fig. 9) presumn - s perconducting coils as the storage devices. Thyristor bridges are required to convert the de of the coils to the power grid liequency. At 0.1 cent per joule of stored energy, the cost of masnotic field storage is 250 million dollars.

\section{Capacitors}

Electric lifld storage in capacitor banks has been shown in other studies to be one of the most expensive ways to store large amounts of energy.

4. Pumped Starage

Pumped storage (see Fig. 10) can be emplayed by integration of Pelton or Francis hydraulic turbines with the steam turbine generator units. In this case 250 MW units are considered he- 
cause the extrapolation of present1y available turbines and/or gears to $1000 \mathrm{MW}$ units appears to be impractical within the time frame considered.

There are two possible approaches, both requiring development. Steam turbine generator unit operation is at $1800 \mathrm{rpm}$. Pelton or Francis turbine operation is in the 100 to $450 \mathrm{rpm}$ range. Development is required to produce either an $1800 \mathbf{r p m}$ hydraulic turbine or a 250 MWe gear.

A pumped hydraulic storage source is required to provide the typically 1000 to 2500 feet of head. A compressed air equivalent of the typical head requires a pressurized volume of water and air not unlike that utilized for the flash steam energy storage approach.

Uninstalled cost of a pumped storage complex, considering only the costs of gears or turbines ( $\varepsilon_{\text {fter }}$ development has been completed), pumped storaje pressure tanks and pumps amounts to 75 to 100 million dollars.

\section{Power Company Operating Procedures}

Imaginative investigation of power company operating procedures and capabilities could result in determination of system overload capability such that the hybrid reactor downtime, with its associated reduction of output power, could be tolerated by the power grid. It is true at present that instantaneous load assumption or rejection of $1000 \mathrm{MW}$ is tolerated.

\section{Tokamak Commutation}

An alternative possibility is installation of a sufficient number of tokamak reactor plants so that, if ten plants can carry 
full load, an eleventh one is provided, and the plant cycles are controlled so that no more than one plant at a time is in its downtime. The cost of this approach, per plant, is $10 \%$ of the cost of the eleventh plant, or 350 million dollars.

IV Summary

Table I summarizes the estimated costs of the various energy storage approaches considered. Many of the costs represent only a part of the energy storage hardware, but the values are high enough to indicate that other approaches should be pursued.

V Conclusions

Two conclusions result from the foregoing jnvestifation:

1) Energy storage to ride through reactor downtime can be provided inexpensively.

2) The flash steam approach appears to be thr one to pursue. 
Table I. Estimated custs of Energy Storage Approaches

Estimated Cost

Millions

Flibe Loop

Extra Flibe

$\$ 640$

HTS

Inr i um Loop

Hot Rock Bed

$\$ 100$

ivci i um/Stean Interface

Fluidized Bed Negligible

Flash Steam

Negligible

$\$ 850$

F'lywhel Machines

Superconducting Coils

Capacitors

Pumped Storage

Power Company

Operating Procedures

Hybrid Plant

Commutation
Possibly

Negligible

$\$ 350$
Comments

Flibe Only

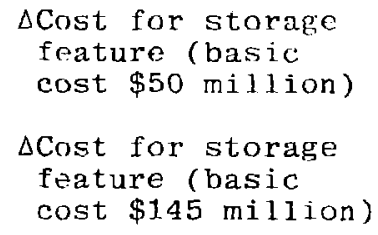

$\triangle$ Cost for storage feature (basic cost $\$ 50 \mathrm{mill}$ ion)

$\Delta$ Cost for storage feature (basic cost $\$ 145$ million)

$\$ 250$

Coils only

Prohibitive

$\$ 100$

Gears/turbines, pressure tanks, pumps on $1 y$

NOTE: All Casts Uninstalled 


\section{Jeterences}

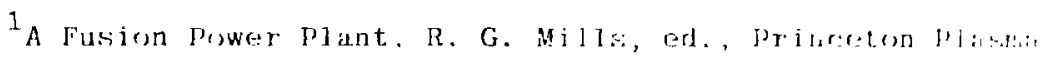
Thysics Latberitory Roport MATT-1050 (1974).

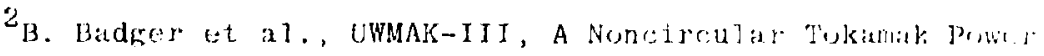

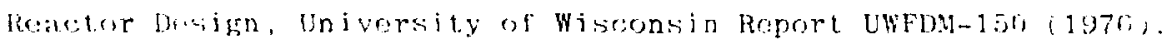

${ }^{3}$ K. Siku, Josign Study of a Heat Reservoir System ior in

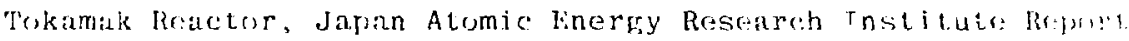
JAI:RI-M 6099 (1975). 
Acknuwledgment

This work was supported in part by the U.S. Department of Energy Contract No. EY-76-C-02-3073. 


\section{Figure Captions}

Fig. 1. Tokamak Reactor Energy Transfer.

Fig. 2. Tokamak Reactor Energy Storage Systems Flibe Joop.

Fig. 3. Tokamak Reactor Energy Storage Systems Flibe Loop. Series.

Fig. 4. Tokamak Reactor Energy Storage Systems Helium Iuspr

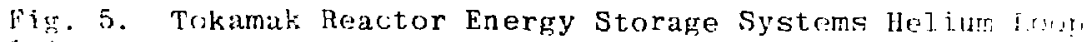
Parallel.

Fir. 6. Trkamak Reactor Energy Storage Systems He] ium/Sarm Interfuce.

Fis. 7. Tokamak Reactor Energy Storage Systrms Water/sital: Interface.

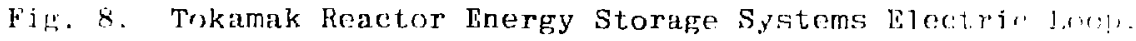

Fin. 9. Tokamak Reactor Energy Storage Systems filectrie frup.

Fin. 10. Tokamak Reactor Energy Storage Systems Electric lour. 


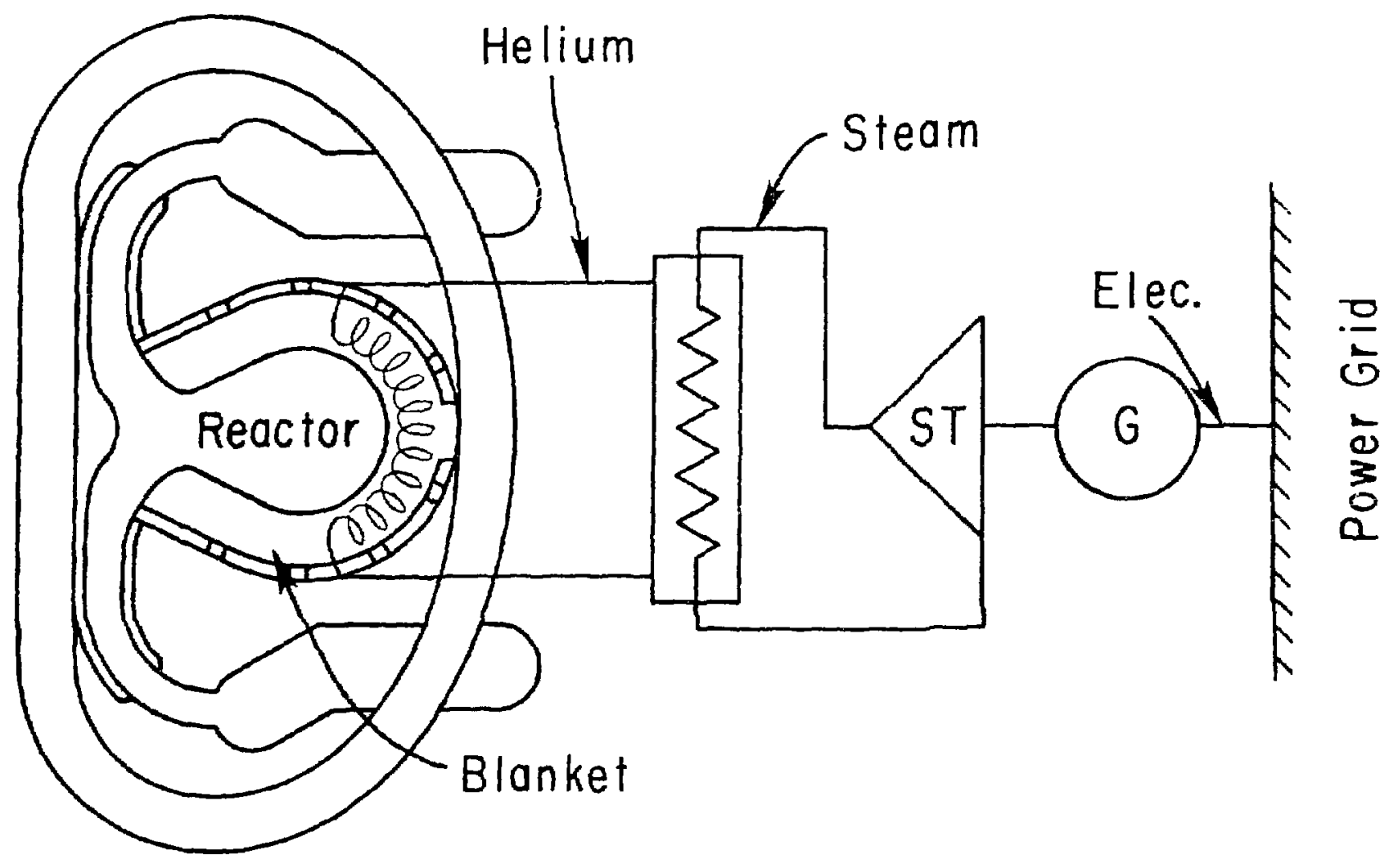




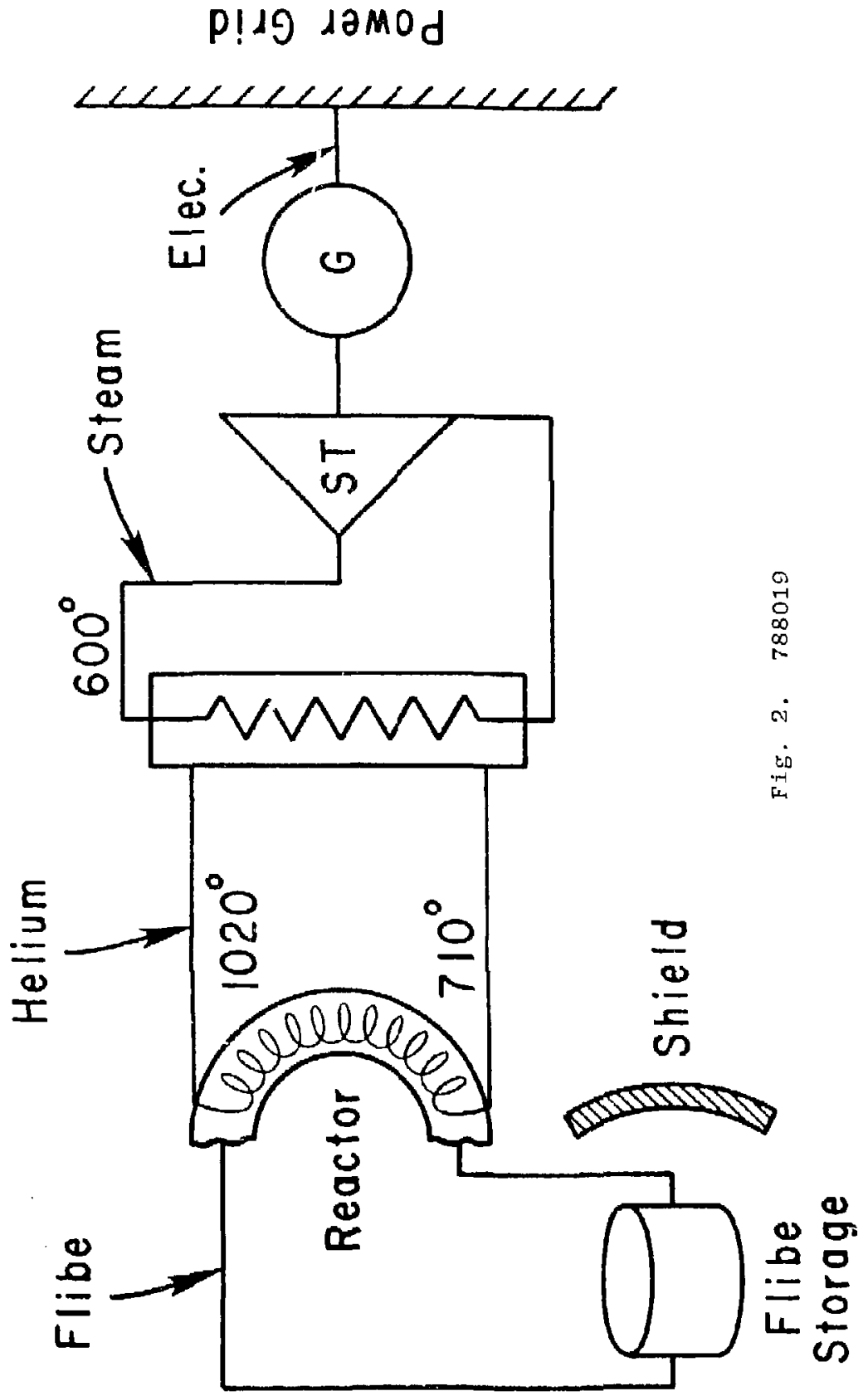




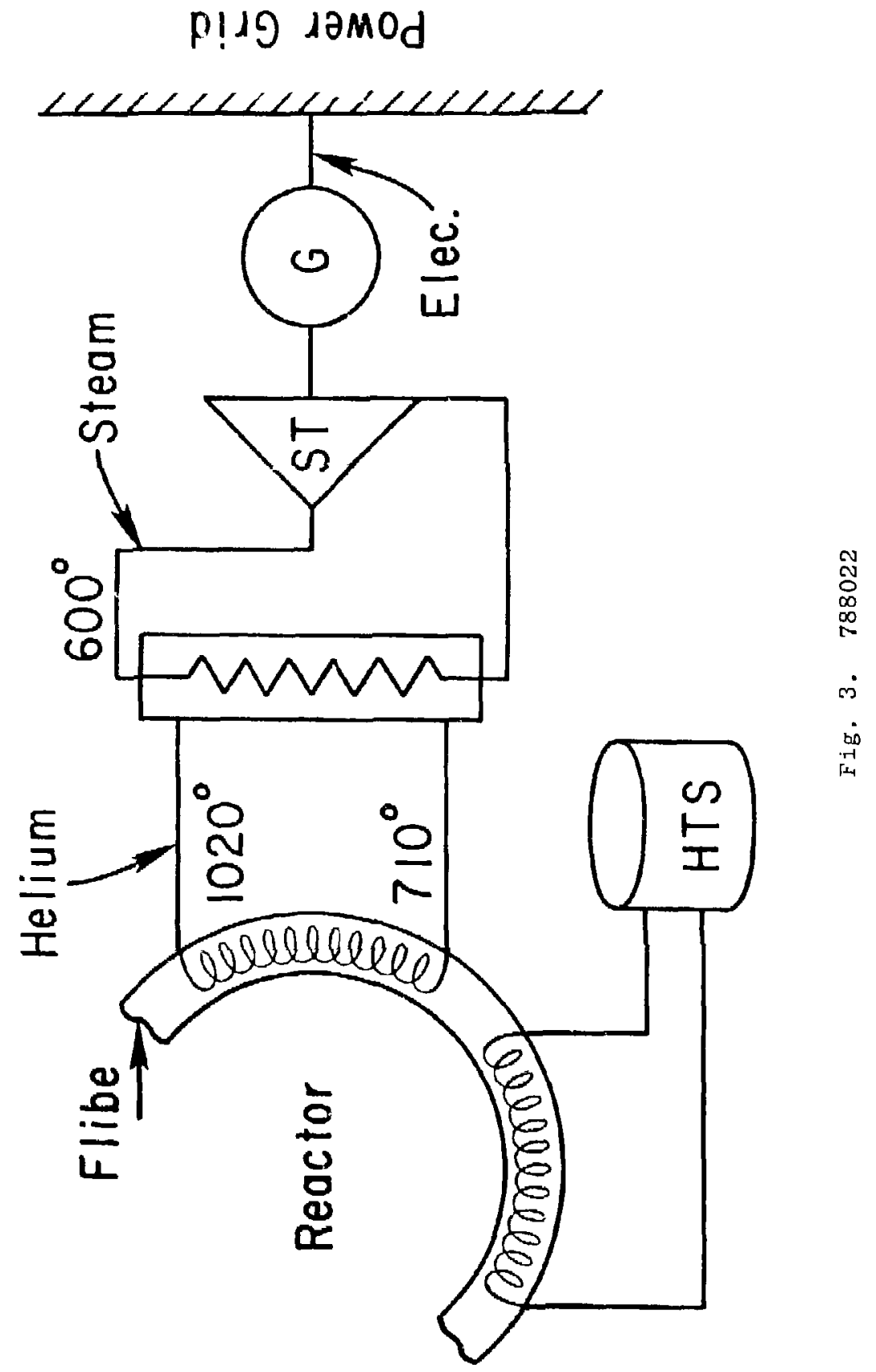




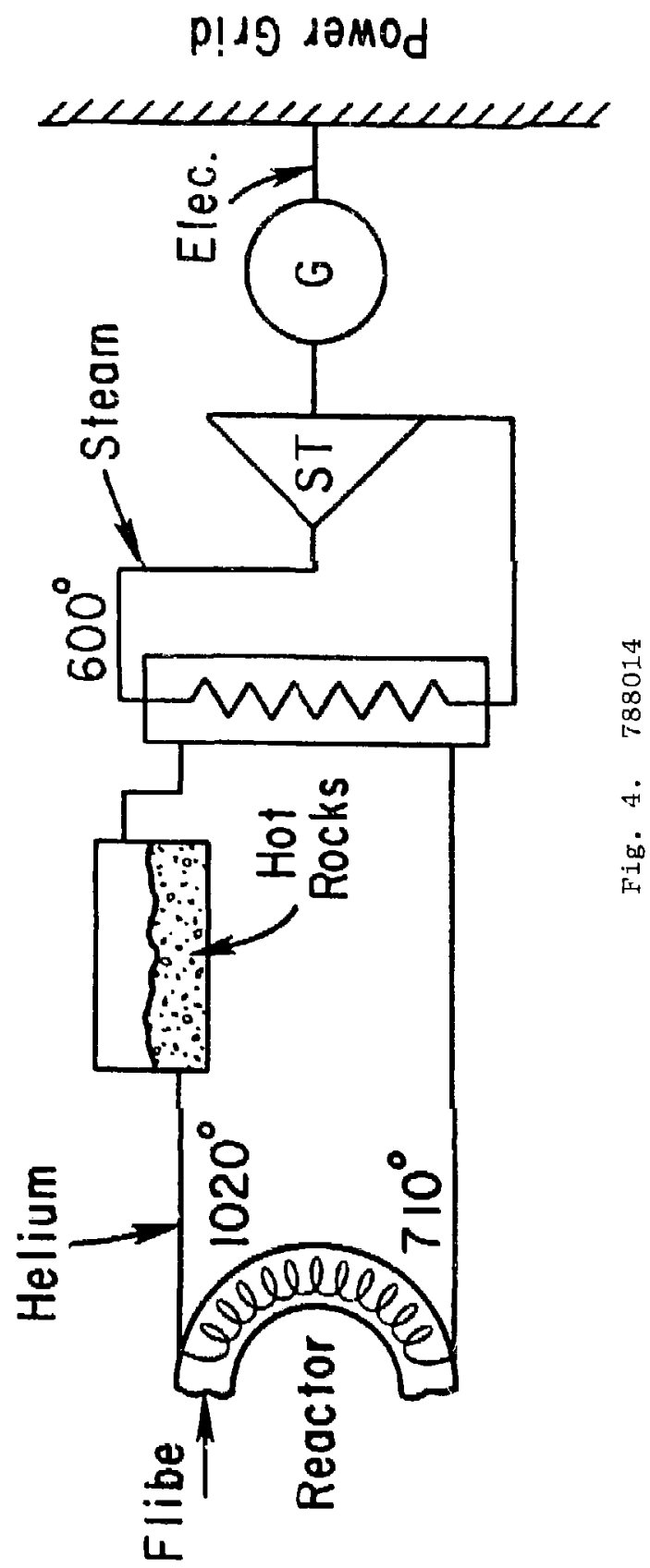




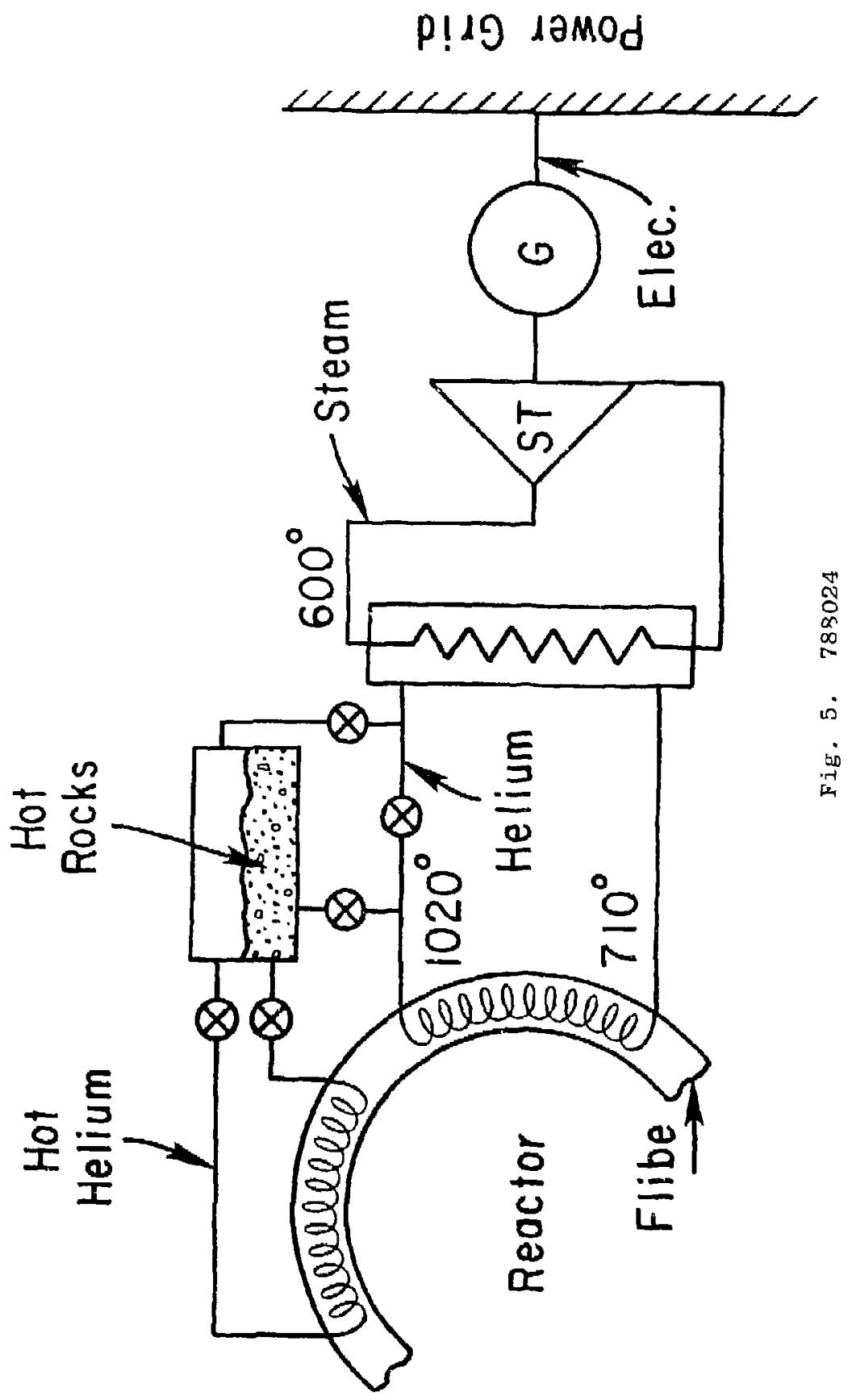




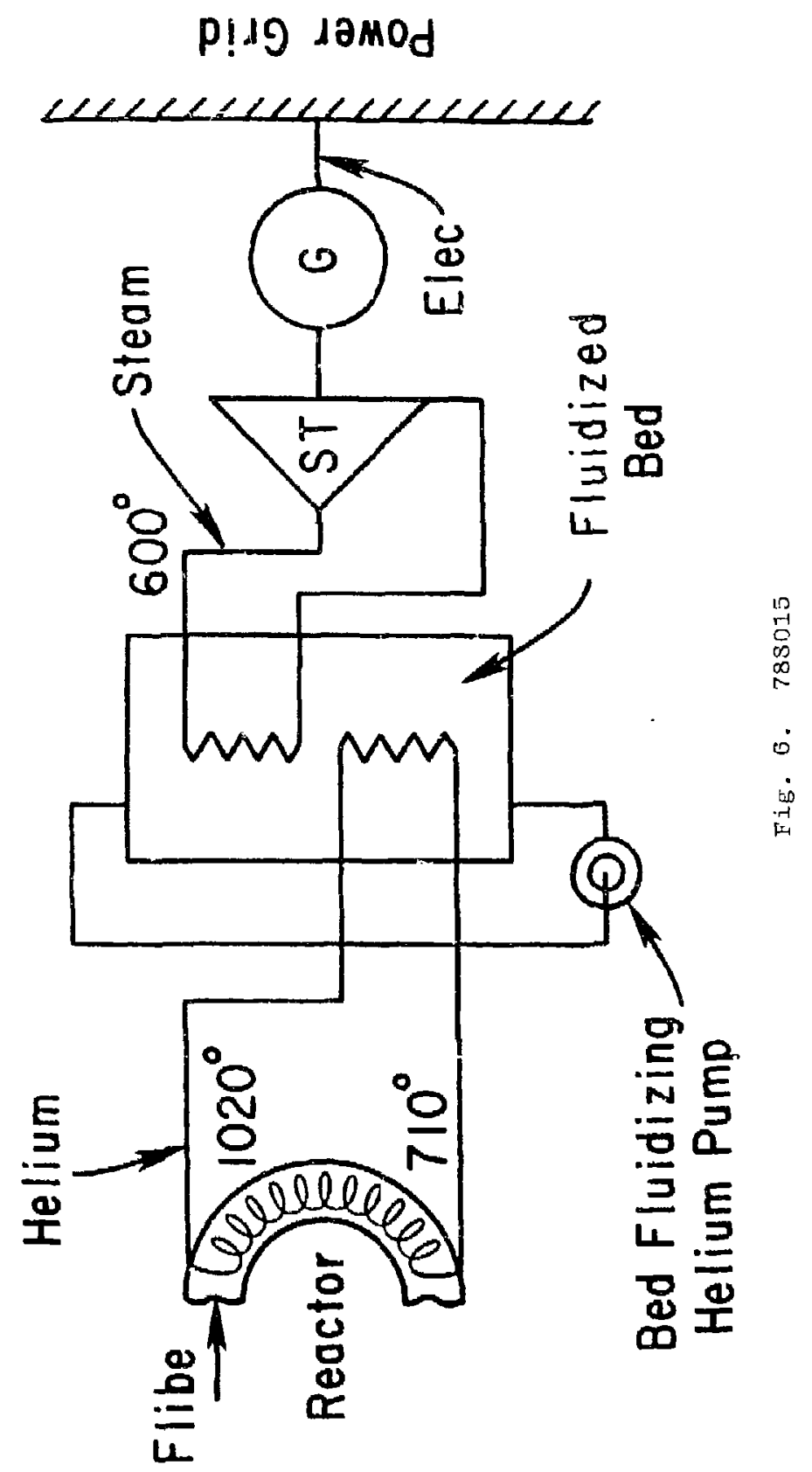




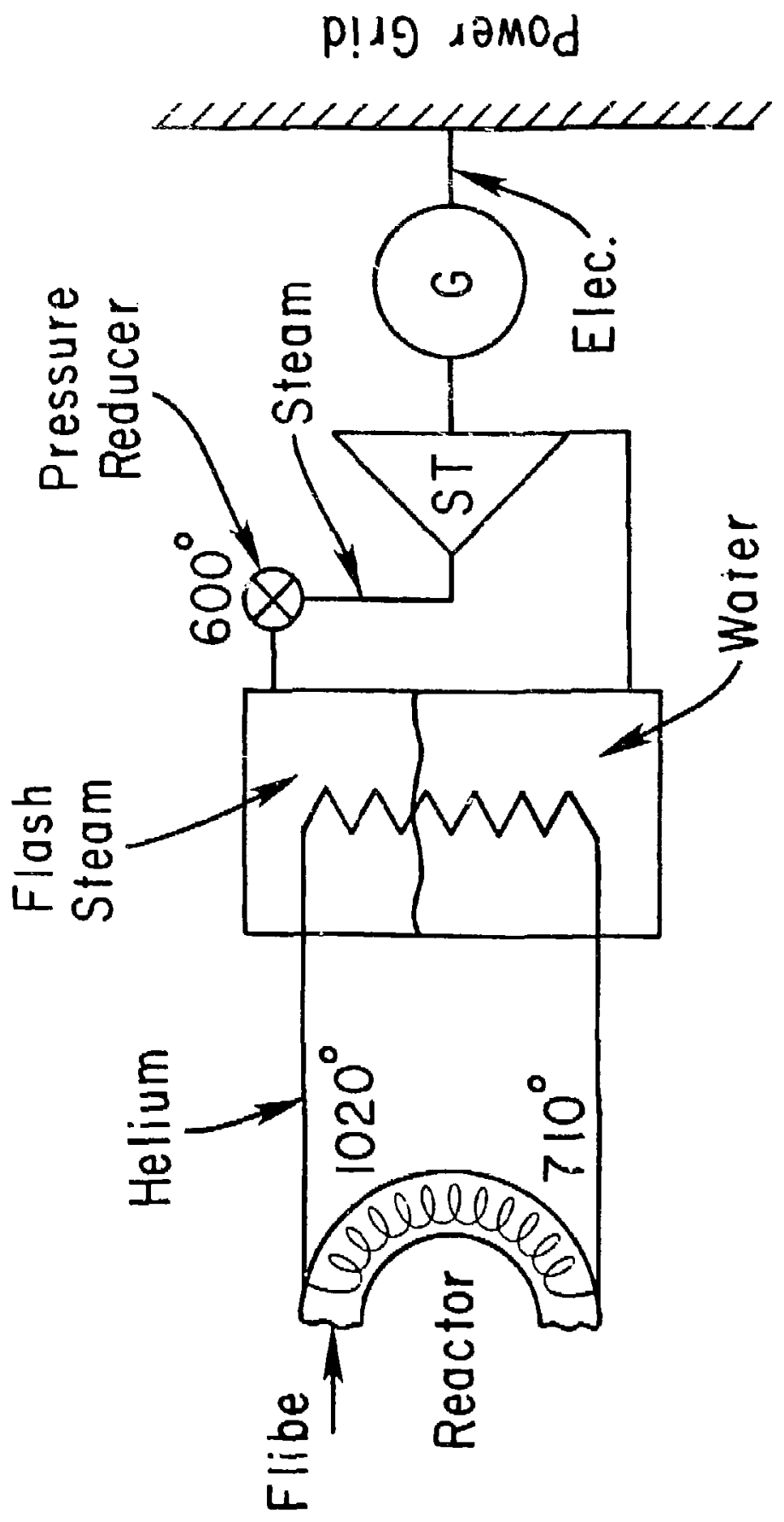

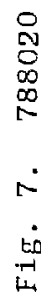




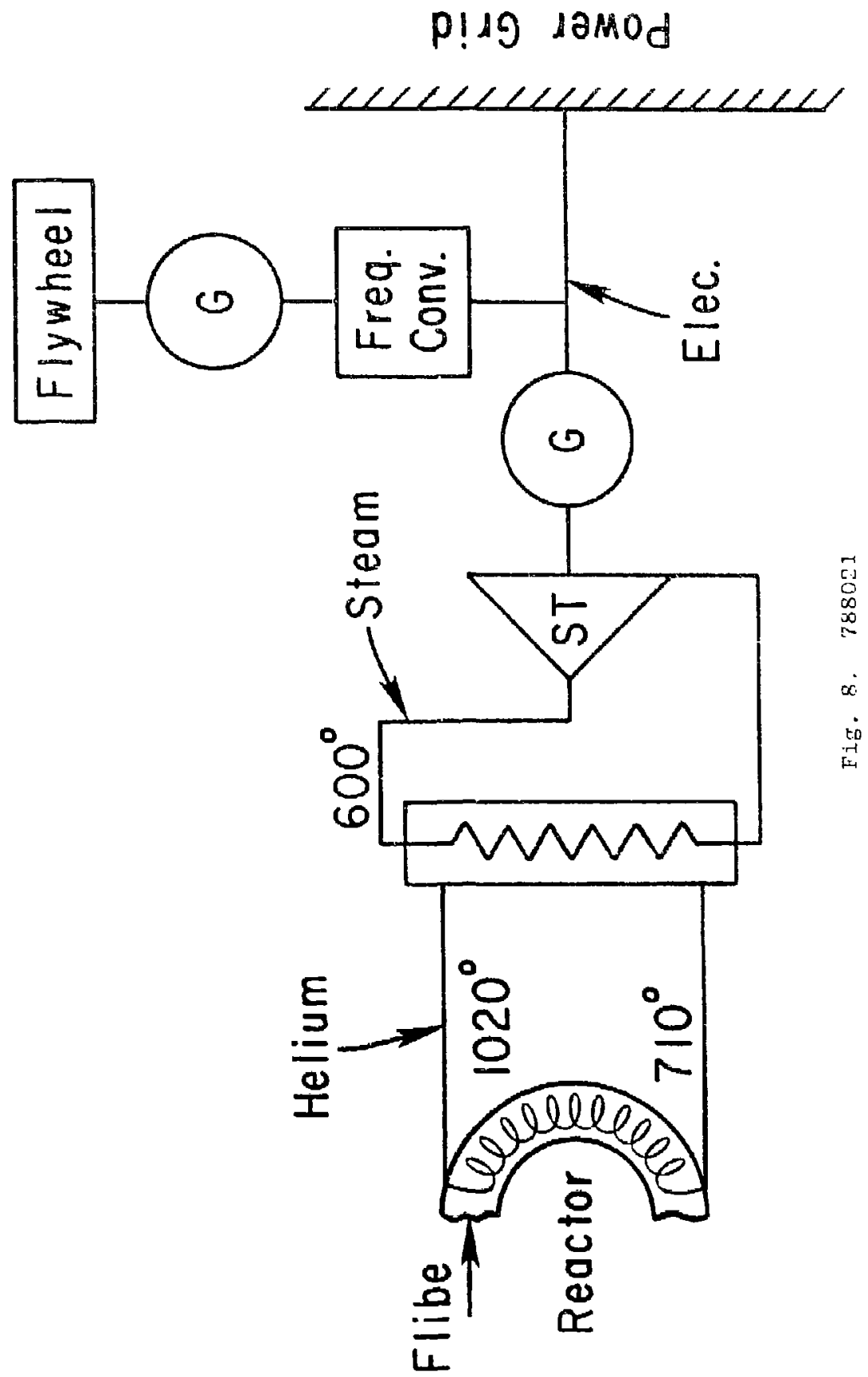




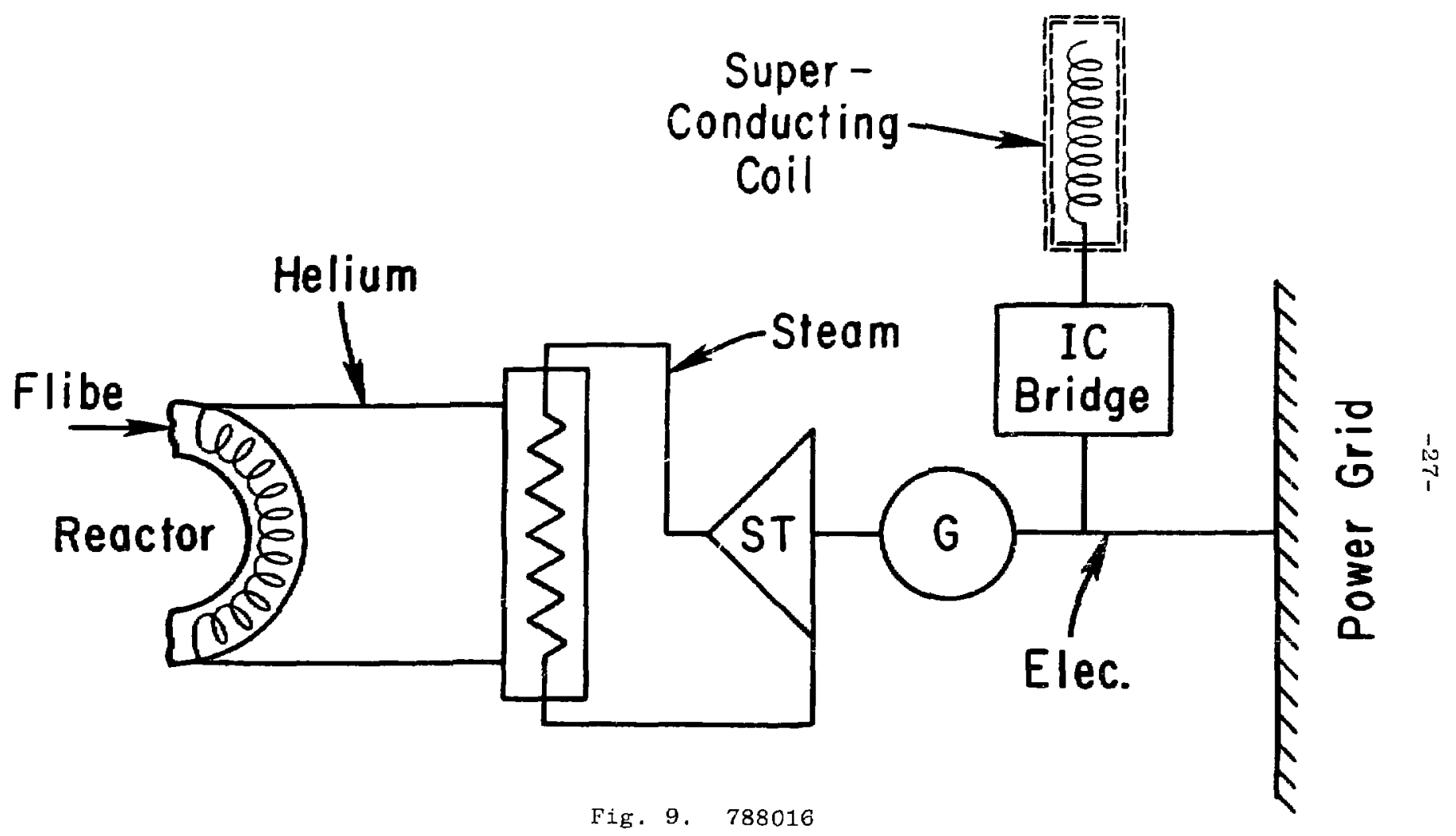




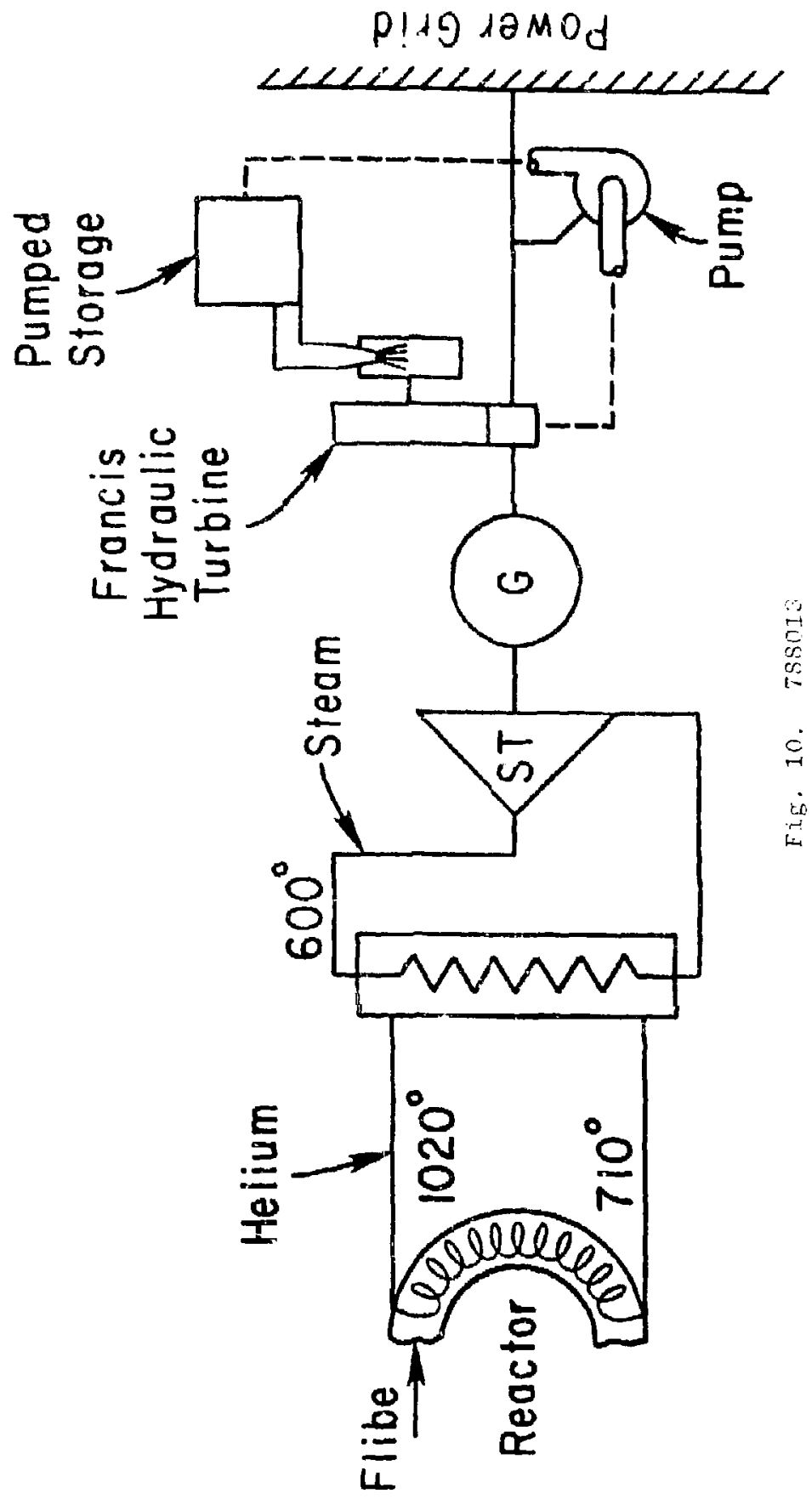




\section{ALLE ITEC, IR!CS}

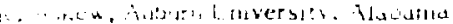

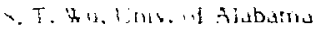

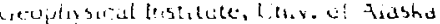

4.L. Johnstor, Sonoma State Lniv. California

1. il. Kuth! ,liniv, of S. Califorria

lisictute tor Energy Siudies, Stanford University

11. 1). Calmpbell, Huversity of Florida

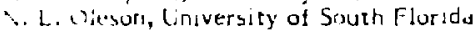

1. 11. Sture'y, Georgia Institute of Technology

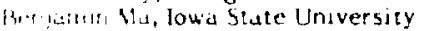

Man', Krytiansen. Texas Tech. University

'A. 1. 'd ase. 'ut'l kurcall of Standards, Wash., D.C.

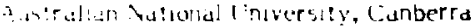

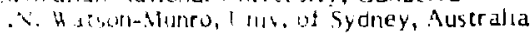

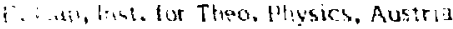

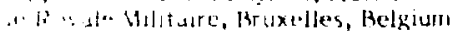

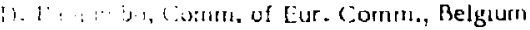

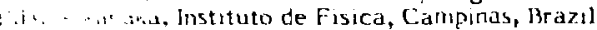

ires, Linversity of Alberta, Canadd

intom. INt i-Energie, Vareerses. Quebec

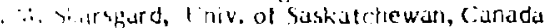
: ati, Clillidill Labordtory, Abingdon, England

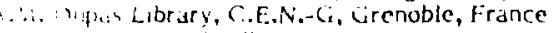

(entall tires. inst. for Physics, Hungaty

k. Yhankl, Mecrut College, India

11. Yurdghi, Atomic: Energy Org. of Iran

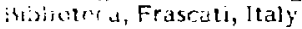

Whb!lotes. Miluno, Italy

. Kostagin. I Jniv. Di Padova, Padova, Italy

'*., „rit? Librury, Inst. de Fisica, Pisa, ltaly

..r.1! ¿ Pasma Physirs Lab., Gokzsho, IJj, Japan

¿.: - iupan Atomic Energy Res. Inst.,Tokai-Mura

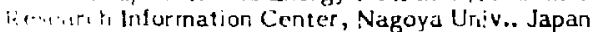

4. '1.'weil. Tokyo Inst. ol Tech.,Japan

I: hr isf Spate \& Acro. Sci., Univ. of Tokyo

T. i. chidd, liniv. of Tokyo, Japan

1.. Yarrato, Toshiba R, \& D. Center, Japan

19. Jushikawa, JAERI, Tokai Rrs. Est., Japan

$\checkmark$ 'injima, Ky'shu Iniv., Japan

h. T.rigland, l! liv. Nacional Auto-noma de Mexico

13. 4. Liley, Lniv. of Waikato, New Zealand

S. A. Moss, Saab Univas Norge, Norway

7.A.C. Cabral, Uniy. de Lisboa, Portugal

ט. Petrus, AL.l. CUZA Univ., Romania

3. de Villiers, Atomic Energy Bd., South Alrica

A. Maurech, Comisaria De La Energy y Recoursos Minerales, Spain

Library, Royal Institute of Technology, Sweden

Cen. de Res. En Phys.Des Plasmas, Switzerland

Librarian, Fom-Instituut Voor Plasma-Fysica, The Netherlands

V. E. Golant, A.F. Ioffe Physical-Tech. Inst.,USSR

B.B. Kadorntsev, Kurchatov Inst. of Atom.: Energy, USSR

The Kharkov Physical-Tech. Inst., USSR

M. S. Rabinovich, Academy of Sci, USSR

Bibliothek, Stuttgart, West Germany

R.D. Buhler, Univ, of Siuttgart, West Germany

Max-Planck-lnst. fur Plasmaphysik, W. Germany

Nucl. Re5. Estab,, Julich, West Germany

K. Schindler, Inst. Fur Theo. Physik, W. Germany

\section{EXPERIATENTAL \\ THEORETK 21}

M. H. Brennan, Flinders Univ. Australia

H. Barnard, Univ of British Columbla, inada

5. Screenivasan, Iniv. of Lalgary, Canada

J. Radet, C.E.N.-B.P., Fontendy-aux-Roses, Frunce Prof. Schatzman, Observatore de Nice, France

S. C. Sharma, Univ. of Cape Coast, Gharid

R. N. Aiyer, Laser Section, indid

B. Buti, Physical Res. Lab., Indi.

L. K. Chavda, S. Gujarat IIniv.. Indis

I.M. Las Das, Banaras Hindulimv., Indid

S. Cuperman, Tel Aviv Intw.. lurael

E. Greenspan, Nuc. Rizs. Conter, lstarel

P. Rosenau, Israel lnst. of Texh., Mritel

Int'l. Center for Theo. Physics. Trasice. Ituly

I. Kawakarnı, Nihon L niver it ty. lupan

T. Nakayama, Ritsumeikan ! ins., Jupun

S. Nagao, Tohoku Univ., 7upun

J.I. Sakai, Toyama Limli, lapun

S. T'jotta, Univ. I Ber:zerl, Norwity

M. A. Hellberg, Univ, of Natal, Susth Rfrice

H. Withelmson, Challers liniv. of Terh., Sweden

Astro. Inst., Sonnenburgh (Jbs., The Netherlands

N.G. Tsintsadze, Acadeny of Sri GSSR, USSR

T. J. Boyd, Univ. Sollege of North Wales

K. Hubner, Univ. Heidelber g, W. Cicrmany

H. J. Kaeppeler, Univ. of Stuttgart, West Germany

K. H. Spatschek, Univ. Essen, West Germany

\section{EXPERIMENTAL \\ ENGINEERING}

B. Grik, Univ. de Quebec, Canudu

P. Lukac, Kornenskeho Univ., Czechoslovakia

G. Horikoshi, Nat'l Liat for High Energy Physics, Tsukuba-Gun, Japán

V. A. Glukhikh, D.V. Etremoy Sci.

Res. Instit.of Elect. App., USSR

\section{EXPERIMENTAL}

F. J. Paoloni, Univ, of Wollongong, Australia

3. Kistemaker, Fom Inst. for Atomic

\& Molec. Physics, The Netherlands

\section{THEORETICAL}

F. Verheest, Inst. Vor Theo. Mech., Belgium

J. Teichmann, Univ. of Montreal, Canada

T. Kahan, Univ. Paris VIl, France

R. K. Chhajlani, India

S. K. Trehan, Panjab Uniy., India

T. Namikawa, Osaka City Univ., Japan

H. Narumi, Univ. of Hiroshima, Japan

Korea Atomic Energy Res. Inst., Korea

E. T. Karlson, Uppsala Univ., Sweden

L. Stenflo, Univ. of UMEA, Sweden

J. R. Saraf, New Univ., United Kingdom 